\title{
Cost-efficiency analysis of a runoff detention reservoir with integrated hydraulic and structural dimensioning
}

\author{
Análise custo-eficiência de reservatório de retardo do escoamento com integração entre \\ dimensionamentos hidráulico e estrutural
}

\author{
Victor Santos Galvão Baptista ${ }^{1}$ and Adriano Rolim da Paz ${ }^{1}$ \\ ${ }^{1}$ Programa de Pós-graduação em Engenharia Civil e Ambiental, Centro de Tecnologia, Universidade Federal da Paraíba, João Pessoa, PB, Brasil \\ Emails: victorsgb@gmail.com (VSGB), adrianorpaz@yahoo.com.br (ARP)
}

Received: October 18, 2017 - Revised: May 04, 2018 - Accepted: June 20, 2018

\begin{abstract}
In Brazil, urbanization-dominated imperviousness is prevalent, increasing the incidence and magnitude of floods. An alternative to control this impact is an on-site runoff detention reservoir. The choice of reservoir adopted should ideally combine hydraulic/hydrological and structural/economic criteria, although there is a gap in the literature regarding this type of integrated analysis. In this article, a cost-efficiency analysis is conducted to select a reservoir to control the runoff captured by a roof $\left(4,657 \mathrm{~m}^{2}\right)$ using the Puls method for hydraulic dimensioning and based on technical standards for the design of concrete structures. The results indicate that a decrease of approximately $3 \%$ in the theoretically ideal efficiency $(100 \%)$ of the reservoir provided a $36 \%$ drop in cost. Such an alternative is more likely to become attractive and economically viable, with virtually the same benefits to the downstream stormwater drainage system. The analysis of different alternatives induced a decision between the level of control of the reservoir output and the cost that emphasized different aspects, focusing on more than the minimization of the cost or the imposition of a pre-defined control level in an arbitrary way.
\end{abstract}

Keywords: Puls method; Urban hydrology; Source control.

\section{RESUMO}

No Brasil, prevalece a urbanização dominada pela impermeabilização com aumento da incidência e magnitude de inundações. Uma alternativa para controle desse impacto é o reservatório de amortecimento de vazões ao nível do lote. A escolha do reservatório a adotar idealmente deve combinar os critérios hidráulicos/hidrológicos e estruturais/econômicos, embora haja uma lacuna na literatura quanto a esse tipo de análise integrada. Neste artigo é feita a análise custo-eficiência para seleção de um reservatório para controlar o escoamento captado por uma cobertura $\left(4657 \mathrm{~m}^{2}\right)$, usando o método de Puls para o dimensionamento hidráulico e com base em normas técnicas de projeto de estruturas de concreto. Os resultados obtidos indicam que a redução em torno de 3\% na eficiência teoricamente ideal (100\%) do reservatório proporcionou uma queda de cerca de 36\% no custo. Tal alternativa tem mais chance de se tornar atrativa e viável economicamente, mantendo praticamente o mesmo benefício para o sistema de drenagem pluvial a jusante. A análise de diferentes alternativas induziu a uma decisão entre nível de controle de saída do reservatório e custo que ressaltasse diferentes aspectos, e não apenas a minimização do custo ou a imposição de um nível de controle pré-definido de forma arbitrária.

Palavras-chave: Método de Puls; Hidrologia urbana; Controle na fonte. 


\section{INTRODUCTION}

Urban drainage of stormwater in Brazil has generally been inadequately and unsustainably addressed. The traditional approach consists of transferring stormwater downstream through mediumand large-scale structural measures such as the construction of canals and tunnels. These structures contribute to an increase in the peak flow and the frequency of floods, causing damages such as loss of life, interruptions to economic activities and contamination by waterborne diseases (SHUSTER et al., 2005; CANHOLI, 2014). In addition, urbanization dominated by imperviousness increases the incidence and magnitude of floods (MENDIONDO; MENDES, 2007), and without integrated planning with macrodrainage, it often causes the need for expansions in the existing system (e.g., GURGEL; RIGHET'TO 2016; REZENDE et al., 2013). Expanding the existing system involves costs associated not only with the hydraulic construction work itself but also with its surroundings, such as the expropriation of lands and the interruption of traffic. The problem is that this type of intervention does not solve the problem but only transfers it downstream, which is clearly unsustainable over time (TUCCI, 2016; BUTLER; DAVIES, 2010; POMPEO, 2000).

In contrast, the sustainable drainage concept proposes that the problems arising from stormwater runoff should not be transferred to other localities and that the proposed solutions be integrated into the urbanization process (CAHILL, 2012; BAPTISTA et al., 2011; TUCCI, 2005; TAVANTI; BARBASSA, 2012). The best solution then becomes the one that causes less environmental and socioeconomic impacts rather than the one that conducts flow more efficiently. The natural flood volume produced in a given watershed should not be increased by its occupation or modification, and the flow control mechanisms should prioritize the natural forms of flow (TUCCI, 2005). This principle has guided the development of urban drainage master plans (VILLANUEVA; TASSI, 2004). This type of solution can also include additional environmental services such as water security, maintaining the health of water bodies, and increasing recreational and landscape values (BRENT et al., 2017).

In addition to non-structural measures related to the regulation of urban drainage (TUCCI, 2016; TUCCI; MELLER, 2007), the use of devices for source control stands out and has been referred to as compensatory techniques (BAPTISTA et al., 2011; SOUZA et al., 2012; BRASIL, 2006). Due to the mechanisms of infiltration or storage (or the combination of both) of stormwater at the runoff source, such devices compensate for the increased runoff resulting from the imperviousness of part of the land and aim to revert the behavior of the watershed to the pre-urbanization condition (HAMEL et al., 2013; LI et al., 2017). Examples include infiltration trenches (SOUZA, 2002), permeable pavements (CASTRO et al., 2013; BRUNO et al., 2013; TUCCI et al., 2000), green roofs (TASSI et al., 2014; LAMERA et al., 2014) and on-site reservoirs (VILLANUEVA; TASSI, 2004; COSTA JÚNIOR; BARBASSA, 2006; SILVEIRA et al., 1998; GENZ, 1994), in addition to disconnecting downspouts and impervious surfaces that direct the captured water to lawns (CARMEN et al., 2016).

The use of on-site runoff detention reservoirs is considered one of the most widespread runoff source-control measures among compensatory techniques in Brazil. This is due to the practicality of execution/maintenance and because this type of structure is already used for other purposes, which favors its acceptance. This type of device is also explicitly encouraged or even required by municipal laws created to help control the impact of imperviousness on flood amplification such as in the cases of Porto Alegre, Curitiba, Rio de Janeiro and São Paulo. Another advantage is that the water accumulated in the rain control reservoir can be directed to another reservoir for reuse of stormwater, as established in some municipal laws.

Instead of enforcing through regulations the use of structures such as reservoirs, another approach is the creation of a tax benefit for the landholder as a viable solution for population engagement in the adoption of on-site control measures (LENGLER et al., 2014). The landholder would receive full or partial compensation of the private expenses to build the reservoir, which could be accomplished with the exemption of the urban land and property tax (IPTU, for its abbreviation in Portuguese) for a certain period. Alternatively, the collection of an urban drainage tax could induce the implementation of on-site reservoirs due to the possibility of reducing this tax (CANÇADO et al., 2005).

The on-site reservoir delays surface runoff in order to attenuate, reduce and delay the peak flow of stormwater to the downstream public systems, as indicated by experimental studies (AGRA, 2001) and numerical simulations (VILLANUEVA; TASSI, 2004; SILVEIRA et al., 1998; GENZ, 1994). This can reduce the costs associated with implementing micro- and macro drainage networks in the downstream stormwater system (VILLANUEVA; TASSI, 2004). However, the adoption of several reservoirs distributed throughout a watershed constitutes a situation with complex operational control and behavior simulation, especially if the reservoir sizes vary.

The cost composition of many individual reservoirs at various sites may exceed the cost of a single macro-reservoir, as demonstrated by Silva and Cabral (2014). In fact, the adoption of a single macro-reservoir may be an alternative to implementing multiple on-site micro-reservoirs (SILVA JÚNIOR et al., 2017), especially in consolidated urbanization areas where the land lots have already been occupied. Hydrological models applied to simulate the entire watershed and micro- and macro-reservoir implementation scenarios, as well as multi-objective optimization techniques, may be useful for designing reservoirs, combined or not with other compensatory techniques (DUAN et al., 2016; HIXON; DYMOND, 2014). However, the combined effect of several reservoirs may even cause an effect opposite to the desired one, leading to the combination of maximum flows in a more critical configuration than before the implementation of the reservoirs (CAHILL, 2012). For this reason, Petrucci et al. (2012) challenge the focus on the maximum generated flow rate criterion in stormwater drainage control, suggesting instead the maximum drained volume criterion.

The Puls method (BUTLER; DAVIES, 2010) is used for dimensioning reservoirs for source control. This method considers the temporal effect of flow routing into a reservoir, which must be controlled. In the Puls method, the stored volume is a function of the inflow hydrograph of the reservoir and of the maximum flow rate to be maintained at the outlet. The advantage of this method is that it allows conducting a hydraulic simulation of the 
reservoir and verifying in a relatively realistic way the reduction of the inflow and the efficiency of the structure in restoring the original runoff conditions in quantitative terms, although more simplified pre-development methods are also used (CANHOLI, 2014; SILVEIRA; GOLDENFUM, 2007).

By simulating the hydraulic behavior of the reservoir with the Puls method, it is possible to obtain different combinations of reservoir size and bottom discharger diameter to meet a desired hydrological control. However, each reservoir has different costs depending on the material and structural design used. Therefore, the reservoir alternative to be adopted should be considered by combining hydraulic/hydrological and structural/economic criteria, although there is a gap in the literature regarding the integrated consideration of these criteria for the purpose of selecting reservoir alternatives. Generally, studies ignore or adopt great simplifications in the structural design of the reservoir, when in fact this can change the choice of the best reservoir configuration. More in-depth studies adopt multi-objective optimization techniques (e.g., DUAN et al., 2016) and consider in this selection of alternatives the risk of failure of the structure and performance indicators such as flooded area, water level and flood duration (e.g., TUNG, 2017).

In this study, a comparative analysis is performed considering the implementation of dozens of different reservoir alternatives in terms of efficiency in the control of runoff generation captured by a rooftop and the corresponding implementation cost. The case study is the design of a reservoir to control the runoff generated by the rooftop $\left(4,657 \mathrm{~m}^{2}\right)$ catchment of a shopping center located in a region of increasing urbanization and recurrent flood problems in the city of João Pessoa, Paraiba. Using the Puls method for hydraulic dimensioning and based on standard NBR 6118/14 (ABNT, 2014), which specifies criteria and standards for the design of concrete structures, we investigate (i) the sensitivity of the variation in reservoir efficiency as a function of its base area, (ii) the relationship between the impact of the development on runoff increase and on the cost required to control it, including the detailed structural dimensioning as governed by said technical norm, and (iii) the reservoir configuration that provides the best cost-benefit ratio.

\section{MATERIALS AND METHODS}

\section{Overview and stages}

This study included three stages (Figure 1). The first stage covered the initial design of a reservoir based on the selection and characterization of the study area, the hydrological analysis to quantify the impact of the development on the generation of surface runoff, and the hydraulic dimensioning of a reservoir for runoff detention and minimization of the impact caused by the development. In the second stage, dozens of reservoir configurations were developed based on the initial design, varying the base area and the diameter of the bottom discharge outlet. For each alternative, structural dimensioning and cost estimation were carried out. The third stage consisted of the cost-efficiency analysis of the set of conceived alternatives. All of these stages are described in the following sections.

\section{Characterization of the case study}

As a case study, a commercial development lot that is almost completely impervious and located at the headwaters of the Cuia River watershed in the city of João Pessoa, the capital of Paraiba state (Figure 2a), was selected. This watershed is approximately $40 \mathrm{~km}^{2}$ and is constantly affected by floods, affecting a significant part of the capital's population (approximately $32.6 \%$ of the city's total population; BRASIL, 2010). Approximately $62 \%$ of the area of the watershed is urban and is largely modified, mainly due to disordered urban expansion and large drainage works (SILVA et al., 2010). The portion of the watershed where the lot is located is characterized as an impervious area in which the urban density is high, with little space for the construction of new buildings (SILVA; SANTOS, 2010). Therefore, it is an area of the city of João Pessoa that needs interventions in the drainage of stormwater with runoff source control, justifying the choice of this area for the case study.



Figure 1. Flowchart of the main stages of the study. 

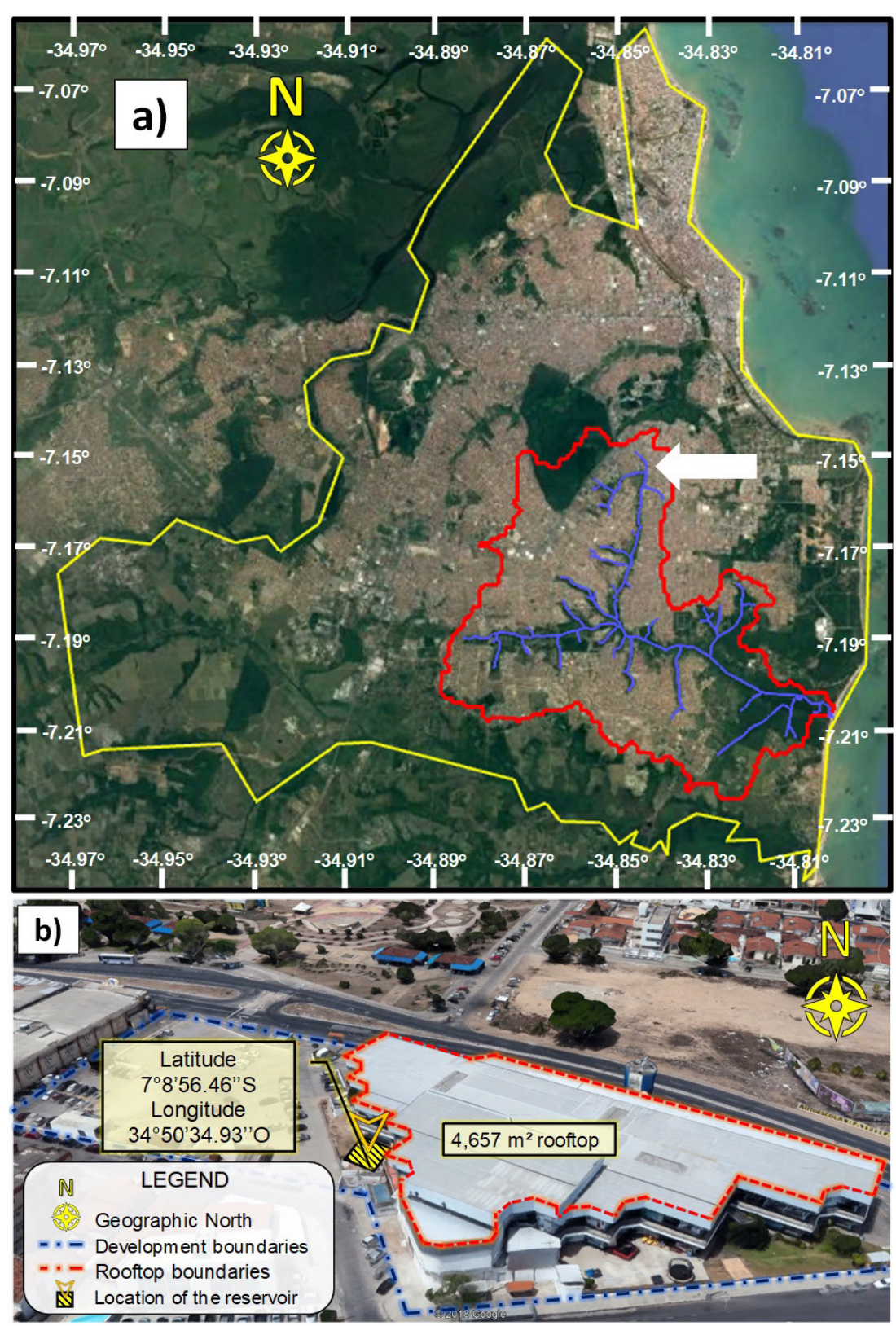

Figure 2. a) Location (WGS 84 lat/long system) of the Cuiá River watershed (in red, with hydrography in blue) in the municipality of João Pessoa (yellow) and location of the lot (white arrow); b) 3D view of the lot in question. (Source: adapted from Google Earth images).

Google Earth software was used to characterize the topography of the land by visualizing the cross-sections of the terrain surface. The rooftop area of the development $\left(4,657 \mathrm{~m}^{2}\right.$, $44 \%$ of the total area of the lot) was defined as the area to be studied and whose runoff would be controlled by a reservoir. The use of runoff detention reservoirs is generally indicated to control runoff captured by rooftops, while the parking and vehicle traffic areas could be controlled with methods such as permeable pavements and infiltration trenches (not addressed in this study).

Two situations were defined: (a) the post-development situation, which includes the rooftop of the building as a catchment area that is entirely impervious, and (b) the pre-development situation, which includes the same rooftop catchment area in the situation prior to the construction of the building, occupied by the original land as an empty lot. The most favorable area for the construction of the reservoir is near the southwest entrance of the parking lot (Figure 2b) because most of the sloping occurs in this direction.

\section{Quantification of pre- and post-development hydrographs}

For the determination of the runoff hydrographs generated in both situations, the time of concentration was calculated, and for a design rainfall, the excess stormwater and the resulting hydrograph were quantified. The conception of hypothetical events that make up critical design situations is usually adopted in urban drainage studies, 
although there are limitations to this approach (SILVEIRA et al., 2000). The time of concentration was determined by the SCS method (Soil Conservation Service; PORTO ALEGRE, 2005) based on the length, slope and roughness information of the flow path and the characteristics of the IDF (intensity-duration-frequency) curve of the region. The times of concentrations of 41.7 and $5.1 \mathrm{~min}$ were estimated for pre- and post-development situations, respectively. For the design rainfall, a return period of five years (SÃO PAULO, 2012) was defined, and the alternating block method (CANHOLI, 2014) was used, with two-minute time discretization and a rainfall duration of $42 \mathrm{~min}$, meeting the requirement to be higher than the time of concentration in both situations.

The SCS method was used to obtain excess stormwater, according to the surface characteristics (soil type and use) and considering the Type II moisture condition since it is an average situation (rainfall less than $40 \mathrm{~mm}$ in the last five days; SÃO PAULO, 2012; TUCCI et al., 1995). The hydrological group of the soil is type C (SUDENE, 1972; GENOVEZ et al., 2005), in which the presence of clay is significant, with layers that prevent the downward flow of water (CANHOLI, 2014). The mean Curve Number $(\mathrm{CN})$ values of the SCS method were 74 and 98 , respectively, for pre- and post-development situations. Based on excess stormwater hyetographs and considering the approach of the SCS synthetic triangular unit hydrograph (CANHOLI, 2014; TUCCI et al., 1995), the hydrographs resulting from the pre- and post-development situations were estimated.

\section{Initial design of reservoirs}

The scope of the analysis of on-site detention reservoirs was restricted to reinforced concrete structures that are square, buried in the ground and subject to passing vehicles. A circular orifice bottom discharge outlet was considered, the purpose of which is to connect to the downstream micro-drainage system. The reservoir input occurs through a water catchment system on the roof of the property. The dimensions of the reservoirs were determined by hydraulic simulations using the Puls method and subsequent structural dimensioning, as detailed below.

\section{Hydraulic simulation of reservoirs}

In this step, the hydraulic simulations were carried out using the Puls method, which operates according to the continuity equation (BUTLER; DAVIES, 2010; COLLISCHONN; DORNELLES, 2013). The inflow rate is given by the post-development hydrograph, while the outflow rate is calculated by the general orifice equation as a function of the hydraulic load and the cross-section of the discharge outlet (PORTO, 2006). Since the inflow and outflow rates are different, there is accumulation throughout the rainfall event and subsequent discharge of the water volume into the system. Approximated by finite differences and after rearrangement, the equation of continuity becomes Equation 1.

$\frac{2 S_{t+\Delta t}}{\Delta t}+Q_{t+\Delta t}=I_{t}+I_{t+\Delta t}+\frac{2 S_{t}}{\Delta t}-Q_{t}$

For the time interval $\Delta t$, it is assumed that $\mathrm{I}$ and $\mathrm{Q}$ are the inflow and outflow rates of the reservoir, respectively, $\mathrm{S}$ is the reservoir volume, and the subscripts $t$ and $t+\Delta t$ are the initial and final times, respectively. Equation 1 is solved using an auxiliary curve prepared from several water depths and respective outflow rates.

The data for runoff simulation are a) the area of the reservoir base, b) adoption of discharge outlet diameter, and c) the definition of the calculation time step. The hydraulic simulation occurs by calculating, for each discrete inflow rate increment, the outflow rate as a function of the auxiliary curve. The volume of water stored for each time step was also calculated. Thus, the Puls method produces the reservoir outlet hydrograph as a response, as well as a diagnosis of water storage over time; the maximum stored volume and the maximum water level define the internal dimensions of the simulated reservoir. Deep reservoirs should be avoided because they hinder gravity drainage into the downstream micro-drainage system. It is also not good to have an emptying time of more than 24 hours since it indicates an increase in the risk of proliferation of waterborne diseases, in addition to increasing the risk of reservoir failure given consecutive rainfall events.

The simulated hydrograph for the system outlet tends to have its peak flow dampened due to the time distribution of the stored water volume. The simulation is then assessed in terms of the required maximum reservoir height, of the efficiency (eff; Equation 2) and abatement (ab; Equation 3) produced in the inlet hydrograph and in terms of the emptying time. The efficiency evaluates how much the maximum flow obtained during the simulation (Qmax,sim) approaches the maximum pre-urbanization flow (Qmax,pre); therefore, the closer they are, the more efficient the bottom discharge outlet-area combination is. In turn, the abatement evaluates how much the simulated maximum flow is dampened in relation to the maximum inflow hydrograph generated in the post-development situation (Qmax,post).

$$
\begin{aligned}
& \text { ef }(\%)=\frac{Q_{\text {max }, \text { sim }}-Q_{\text {max }, \text { post }}}{Q_{\text {max }, \text { pre }}-Q_{\text {max }, \text { post }}} \cdot 100 \\
& a b(\%)=\left[1-\left(\frac{Q_{\max , \text { sim }}}{Q_{\max , \text { post }}}\right)\right] \cdot 100
\end{aligned}
$$

The relationships between Qmax,post and Qmax,pre and between Qmax,sim and Qmax,pre can be written as Equations 4 and 5.

$$
\begin{aligned}
& Q_{\text {max }, \text { post }}=k \cdot Q_{\text {max }, \text { pre }}, k \geq 1 \\
& Q_{\text {max }, \text { sim }}=k^{\prime} \cdot Q_{\text {max }, \text { pre }}
\end{aligned}
$$

Factor $\mathrm{k}$ indicates how many times the maximum postdevelopment flow rate is higher than the maximum pre-development flow rate, evidencing the impact that imperviousness has brought to the area under consideration. The higher the value of $\mathrm{k}$, the greater the restriction requirement of the maximum outflow rate of the reservoir to be simulated. Factor k' represents the ratio between the maximum simulated flow rate and the maximum pre-development flow rate: the higher the k', the lower the flow restriction requirement of the reservoir. From Equations 2, 4 and 5, we can write the relationship between k', $\mathrm{k}$ and ef with Equation 6 .

ef $(\%)=\frac{k^{\prime}-k}{1-k} \cdot 100 ; \forall k>k^{\prime}$ 
It is observed that a k' value of 1 results in an efficiency of $100 \%$ (maximum simulated flow rate equal to the maximum pre-development flow rate), which is theoretically the most appropriate scenario from the perspective of drainage control. For a k' greater than 1, a tolerance is adopted in the control imposed by the reservoir, that is, Qmax,sim > Qmax,pre, and the acceptable efficiency is less than $100 \%$, decreasing with the increase of k', while maintaining the same k (Figure 3a).

If a k'value is stipulated, we have the minimum efficiency acceptable for the reservoir, and the problem is to design it so that Qmax,sim/Qmax,pre does not exceed the set value for k'.

In contrast, the higher the impact of the land occupation is (the greater the $\mathrm{k}$ ) while maintaining the desired value of $\mathrm{k}^{\prime}\left(\mathrm{k}^{\prime} \neq 1\right)$, the greater the minimum acceptable efficiency for meeting the imposed conditions (Figure 3b).

The analysis of Equation 6 is a practical way of knowing which range of reservoir efficiency values can be worked as a function of the level of impact brought about by a development $(\mathrm{k})$ and the level of tolerance to be allowed $\left(\mathrm{k}^{\prime}\right)$, which guides the design and dimensioning process of reservoir alternatives.

In this study, the reservoirs were designed with the $\mathrm{k}$ factor ranging from 1 (a more restricted situation, where maintenance of the maximum pre-development flow rate is required) to 3 (allowed to increase up to three times the maximum pre-development flow rate). The proposal is to evaluate how the efficiency, the dimensioning and the corresponding cost of the reservoirs behave by allowing such flexibility of k'. One of the motivations for this k' factor flexibility is the study by Villanueva and Tassi (2004), whose global analysis of the drainage system for a k' factor equal to 2 was more favorable than the restricted control corresponding to a k' value of 1 . In the above study, considering $k^{\prime}$ equal to 2 provided a modest decrease in efficiency compared to considering a k' of 1 , while leading to lower overall cost (including micro-reservoirs and downstream micro- and macro-drainage system).

\section{Structural dimensioning}

The structural dimensioning of the reservoirs followed the one recommended in the current technical standard NBR 6118/14 and according to the method of Araújo (2010), considering recommendations of the NBR 6120/80 (ABNT, 1980). A 20-cm layer of sandy soil with natural moisture above the cover slab was predicted, which allows the best adjustment of the designed reservoir to the external environment (Table 1). There is also a gap of equal size between the simulated maximum water level and the height of the cover slab. The reservoirs were designed considering the hydraulically simulated maximum water level in order to maximize the internal hydrostatic pressure.

In terms of durability, NBR 6118/14 addresses some aspects related to stormwater drainage. Among the requirements, it is stated that "the presence or accumulation of stormwater on the surfaces of concrete structures" (NBR 6118/14, item 7.2, ABNT, 2014, p. 18) should be avoided. There is particular concern about movement or expansion joints on surfaces subject to water action, in order to preserve the structure's impermeability. The reservoirs were
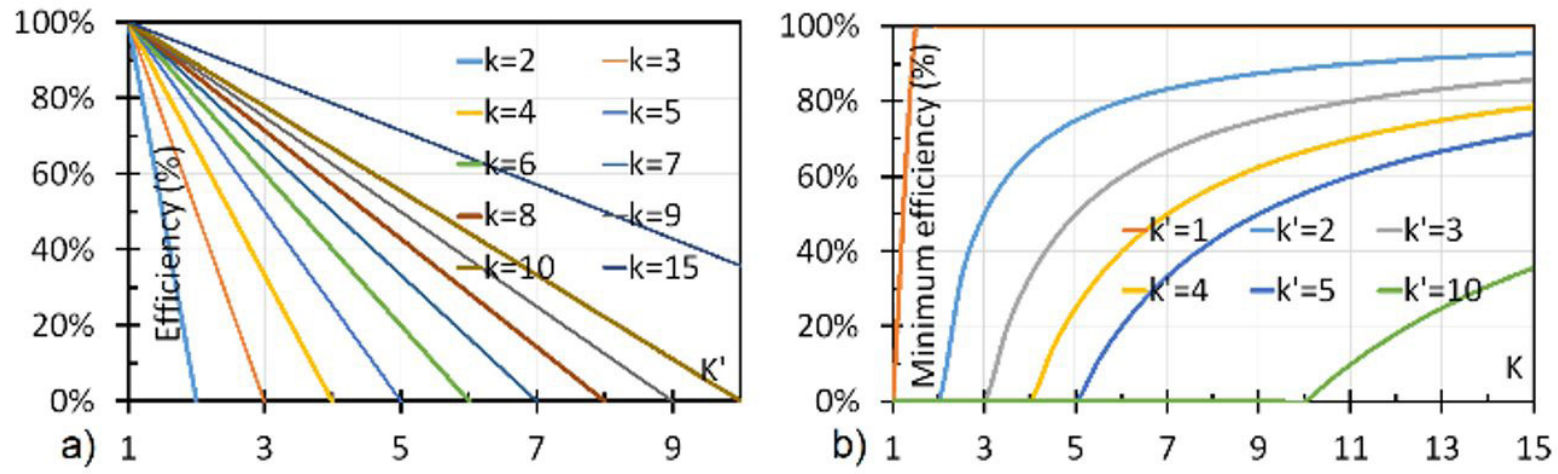

Figure 3. a) Efficiency of the reservoir as a function of k and k'; b) Relationship between minimum efficiency and k and k' values.

Table 1. Main parameters adopted in the structural dimensioning of the reservoirs.

\begin{tabular}{lccc}
\hline \multicolumn{1}{c}{ Parameter } & Value & Unit & Justification \\
\hline Specific weight of reinforced concrete & 25.0 & $\mathrm{kN} / \mathrm{m}^{3}$ & NBR $6120 / 80$ \\
Specific weight of water & 10.0 & $\mathrm{kN} / \mathrm{m}^{3}$ & Adopted \\
Parking overload & 3.0 & $\mathrm{kN} / \mathrm{m}^{3}$ & NBR $6120 / 80$ \\
Specific weight of the soil & 17.0 & $\mathrm{kN} / \mathrm{m}^{3}$ & NBR $6120 / 80$ \\
Soil friction angle & 30.0 & $\circ$ & NBR $6120 / 80$ \\
Class of environmental aggressiveness & $\mathrm{IV}$ & - & $\mathrm{NBR} 6118 / 14$ \\
Cover (slabs) & 4.5 & $\mathrm{~cm}$ & NBR $6118 / 14$ \\
Cover (beams/pillars) & 5.0 & $\mathrm{MPa}$ & NBR $6118 / 14$ \\
Characteristic compressive strength & 40.0 & $\mathrm{~mm}$ & NBR 6118/14 \\
Maximum diameter of the aggregate & 19.0 & - & Adopted \\
Type of steel adopted & CA-50 A & Adopted \\
\hline
\end{tabular}


designed with covers referring to the environmental aggressiveness class IV, considering that reservoirs, in general, are exposed to environmental conditions considered aggressive.

The cover and bottom slabs were calculated as plates. The sidewalls were calculated as plates and then as beams; the reinforcing steel resulting from the two cases was overlapped due to the principle of overlapping effects (ARAÚJO, 2010). Araújo (2010) also indicates that the fixing conditions are as follows: cover slab supported on the sidewalls and bottom slab and sidewalls mounted on each other, which required the calculation of the rebars at the edges of the reservoir. Based on the imposed demands on the structure, the internal stresses of each isolated piece were automatically calculated with the help of electronic spreadsheets developed by the authors.

In the slab design, we sought to avoid calculating the deflections by considering effective heights greater than the limit height recommended by NBR 6118/14. This procedure made it possible to avoid calculation in the service life limit state for quasi-permanent combinations. For the dimensioning domains, the fourth domain was avoided with the increase in the section inertia by increasing the thickness of the pieces, when necessary, so that there were no sections with double reinforcement.

The design of the lateral walls as a beam passed through a process analogous to that described for the methodology used in the calculation of the slabs. Additionally, there was a need for the beam to be designed as a wall-beam, because of the height, which did not occur for any of the reservoirs.

To calculate the crack aperture in the components (ARAÚJO, 2010), a more rigorous limit was adopted $(0.1 \mathrm{~mm}$ ) due to the greater risk of deterioration in the region. Criteria of limit spacing and minimum anchorage of the reinforcements were also considered. It was not within the scope of this study to go further into the detailing aspects of the structures since the structural design objective was summarized in the determination of the amount of steel used and the thicknesses of slabs and concrete walls, which served as input parameters for the cost estimate calculation performed next.

\section{Cost estimation aspects}

The services considered for the cost estimate preparation were all the necessary ones for the construction of the reservoir and are briefly described in order of execution (Table 2). Initially, mechanized excavation of the natural ground was considered, referred to as Category I soil. The installation of lean concrete ballast was estimated at the base of all excavated ground. For reservoirs that would require excavation above $1.5 \mathrm{~m}$, the excavation of $1.5 \mathrm{~m}$ berms (Figure 4) was considered in order to reduce the risk of soil collapse, since no containment structure was estimated and

Table 2. Services considered in the cost estimates and prices of the compositions.

\begin{tabular}{|c|c|c|}
\hline Item & Unit & Price \\
\hline Excavation & $\mathrm{m}^{3}$ & $\mathrm{R} \$ 5.18$ \\
\hline Concrete ballast at base & $\mathrm{m}^{3}$ & $\mathrm{R} \$ 98.73$ \\
\hline Roughcast on the sidewalls & $\mathrm{m}^{2}$ & $\mathrm{R} \$ 4.03$ \\
\hline Formwork for walls & $m^{2}$ & $\mathrm{R} \$ 160.58$ \\
\hline Formwork for the cover slab & $\mathrm{m}^{2}$ & $\mathrm{R} \$ 58.05$ \\
\hline Manufacture of slab shoring & $\mathrm{m}^{2}$ & $\mathrm{R} \$ 31.71$ \\
\hline Mounting and dismounting of slab shoring & $\mathrm{m}^{2}$ & $\mathrm{R} \$ 1.86$ \\
\hline Dosage, preparation, and mixing of concrete & $\mathrm{m}^{3}$ & $\mathrm{R} \$ 348.78$ \\
\hline Transportation, pouring, compacting and finishing of concrete & $\mathrm{m}^{3}$ & $\mathrm{R} \$ 65.15$ \\
\hline Placement of reinforcement steel for walls & $\mathrm{kg}$ & $\mathrm{R} \$ 6.88$ \\
\hline Placement of reinforcement steel for slabs & $\mathrm{kg}$ & $\mathrm{R} \$ 6.49$ \\
\hline Internal waterproofing & $\mathrm{m}^{2}$ & $\mathrm{R} \$ 47.38$ \\
\hline External waterproofing & $\mathrm{m}^{2}$ & $\mathrm{R} \$ 37.63$ \\
\hline Cleaning & $\mathrm{m}^{2}$ & $\mathrm{R} \$ 6.68$ \\
\hline Backfilling, loading and unloading of tipper trucks & $\mathrm{m}^{3}$ & $\mathrm{R} \$ 26.37$ \\
\hline
\end{tabular}

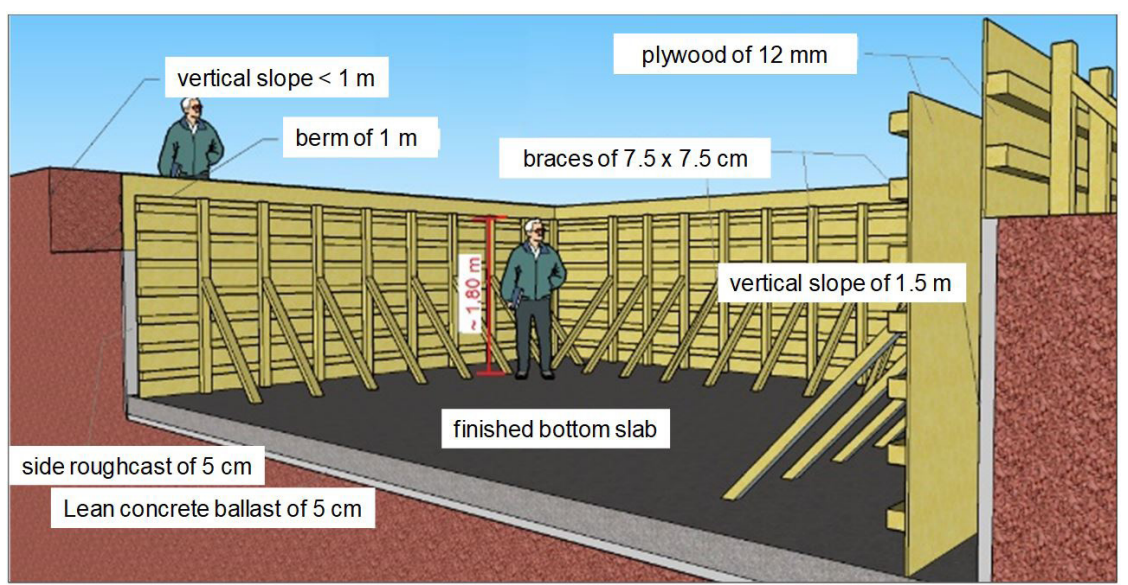

Figure 4. Schematic diagram of the 24th reservoir formworks, modeled using SketchUp software (Trimble). 
there is space in the lot. For the excavated ground walls up to $1.5 \mathrm{~m}$, roughcast was considered in order to prevent the absorption of moisture from the concrete during the curing process, which would be compromised.

Another step taken into account was the mounting of the reinforcement of the bottom slab and subsequent concreting. Concreting was adopted with the concrete prepared at the work site using a concrete mixer. The fabrication and mounting of the wall panels (Figure 4) and the wood shoring to support the formwork panels of the cover slabs were also considered. Waterproofing of the entire structure was estimated by applying four layers of mortar and two coats of bituminous paint on the reservoir cover slab. There was also a consideration of the costs of the general cleaning of the worksite, the backfill of the berms, when necessary, and the loading, transport, and unloading of the soil at the landfill of the region, which was located $18.9 \mathrm{~km}$ from the lot. The cost of the bottom discharge outlet was not computed in the cost estimate because it is negligible in relation to the total cost of the reservoir.

The composition of the services was made based on the consultation in the Table of Price Compositions for Cost Estimates (TCPO, 2010); the prices of the raw materials referenced in the compositions, as well as the hourly cost of the workers, were obtained from the National System of Survey of Costs and Indices of Civil Construction (SINAPI; CAIXA ECONÔMICA FEDERAL, 2017) of February 2017, with no exemption of taxes. The price compositions of the backhoe, loader, and tipper truck were considered based on the official portal of the Secretariat of Infrastructure of the State of Ceará (SEINFRA/CE; CEARÁ, 2017), a reference in the Northeast region of Brazil, although the wages of operators have been replaced by SINAPI local values.

\section{Iterative design process of alternative reservoirs}

Initially, we attempted to design the reservoir in order to strictly comply with $100 \%$ efficiency, that is, total control of the simulated flow rate for abatement to the pre-development flow rate. It was decided not to use diameters smaller than $50 \mathrm{~mm}$ due to the increased risk of clogging with residues. Subsequent simulations were carried out by means of the gradual reduction of the width and length of the reservoir (10 cm discretization), which resulted in the gradual increase in depth and decrease in the efficiency of the system to the minimum efficiency value allowed. Another established criterion was the limitation of the excavation depth to $2.50 \mathrm{~m}$. With the estimation of a cover $20 \mathrm{~cm}$ above the reservoir and estimating that the thickness of the slabs would not exceed that measure, the hydraulic simulations were run until the depth of the reservoir reached approximately $1.80 \mathrm{~m}$. The next step dealt with the structural dimensioning of each of the simulated reservoirs. Based on this and the unit costs of the service compositions, it was possible to obtain the total cost of each reservoir. Through this process, 32 alternative reservoir configurations were created, sized and budgeted.

\section{RESULTS AND DISCUSSION}

\section{Generation of surface runoff}

Considering the area related to the rooftop of the analyzed building, there was an increase in total excess stormwater from $4.5 \mathrm{~mm}$ (11\% of total rainfall) in the pre-development scenario to $34.6 \mathrm{~mm}(86 \%$ of total) (Figure $5 \mathrm{a})$ in the post-development scenario. It is also worth noting that the construction of the building in the study area increased the peak flow rate by approximately $49.4 \mathrm{~L} / \mathrm{s}(875 \%$ growth) relative to the pre-development situation. The maximum post-development flow rate $(\mathrm{Qmax}, \mathrm{post}=55.1 \mathrm{~L} / \mathrm{s})$ obtained is almost 10 times higher than the maximum pre-development flow rate $(\mathrm{Qmax}, \mathrm{pre}=5.7 \mathrm{~L} / \mathrm{s})$, which indicates the need to control the excess surface runoff generated by the building (Figure 5b). The peak time was anticipated by 14 minutes.

\section{Analysis of the initial reservoir design}

The internal dimensions of the reservoir in the initial design were $9.70 \times 9.70 \times 1.17 \mathrm{~m}$, with a bottom discharge outlet $50 \mathrm{~mm}$ in diameter. With this reservoir configuration, the efficiency was $100 \%$, and the peak flow abatement was $89.8 \%$, with a maximum stored water volume of $91.6 \mathrm{~m}^{3}$, which was released over 12 hours (Figure 6a).

For the existing situation, where the maximum flow rate of the land area corresponding to the rooftop (post-development) is almost 10 times greater than the maximum flow rate before the development $(k=9.75)$ and considering that the reservoir acts by causing this outflow rate to be at most 3 times the flow rate


Figure 5. a) Design and excess rainfall hyetographs in the pre- and post-development situations; b) Resulting hydrographs in pre- and post-development situations. 

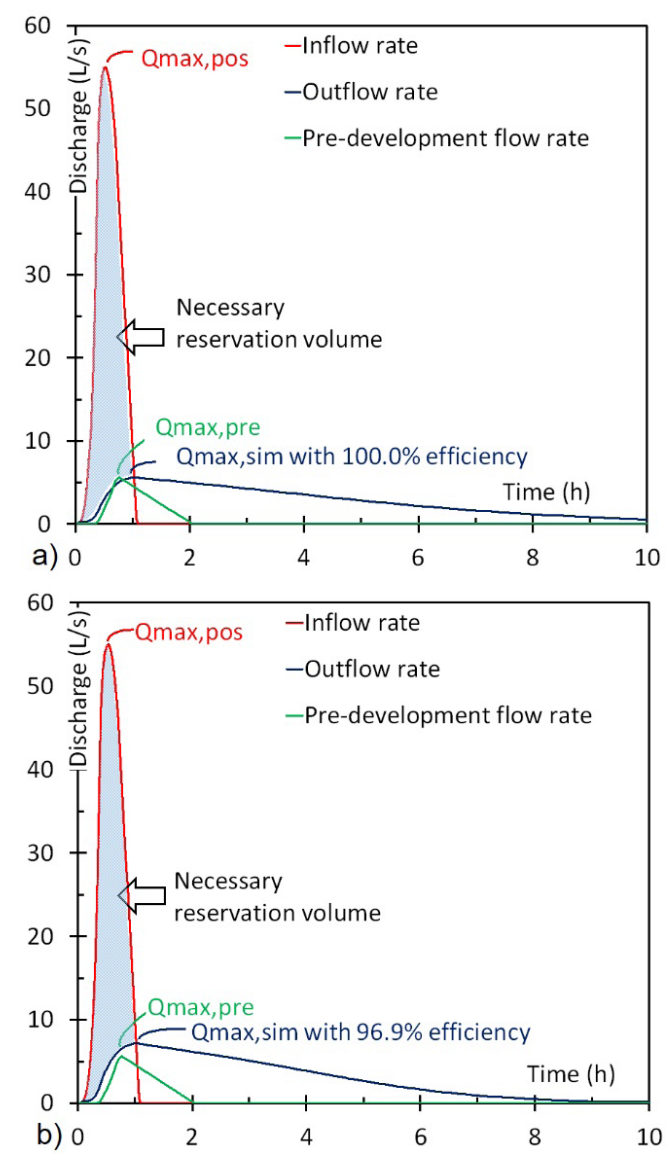

Figure 6. Summary of the simulation a) of the initial reservoir and b) of the reservoir chosen in the cost-efficiency analysis.

before the development $\left(\mathrm{k}^{\prime} \leq 3\right)$, it is estimated that the minimum required efficiency is $77.1 \%$ (Equation 6). Thus, the iterative process of area reduction was performed to reduce the efficiency to that value - reservoirs that provided efficiency $<77.1 \%$ would lead to $k^{\prime}>3$, not meeting the imposed condition.

\section{Cost-efficiency analysis}

The process of hydraulic simulations with the gradual decrease of the internal area caused a gradual increase in the depth, as it was necessary to compensate the dimensions of the reservoir in order to dampen the same inflow hydrograph. This led to an increase in the hydraulic load resulting in a gradual decrease in reservoir efficiency in the subsequent configurations from the initial design with efficiency $=100 \%$, considering that a higher hydraulic load promotes an increase in the outflow of the discharge outlet, maintaining the same diameter. However, the increase in depth occurred, along the iterations, faster than the decrease in efficiency (Figure 7).

Following this process of creating alternative reservoirs, whenever the depth reached the pre-established limit value, larger diameter tubes were adopted so that there was a decrease in depth due to the increase in the outflow rate. Thus, the area reduction

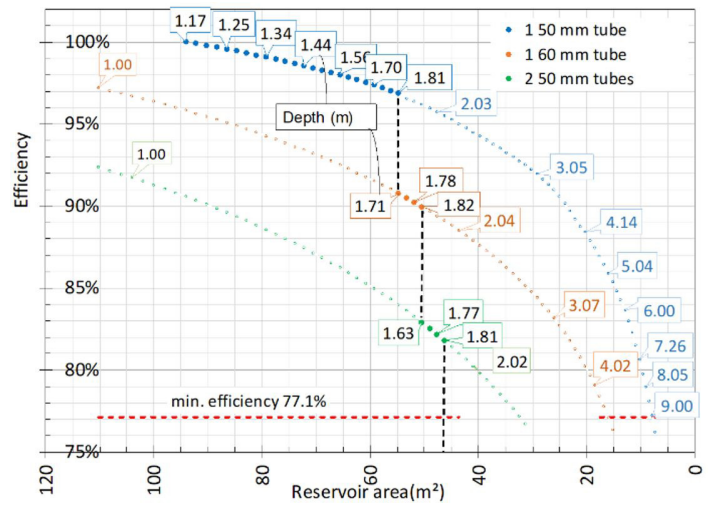

Figure 7. Efficiency of the reservoir as a function of the base area and the diameter of the bottom discharge outlet (depth in meters indicated in the rectangles; larger and solid points indicate the 32 reservoirs that meet the adopted criteria).

process could be continued along a new set of alternative reservoirs, until the depth reached the limit value again.

Each change in diameter caused a discontinuity in the reduction in efficiency until values below the tolerated minimum were reached (efficiency $=77.1 \%$ ) and the iterative process was terminated. A set of 32 different reservoir sizes was obtained, with three different groups of bottom discharge outlets $(1 \phi 50 \mathrm{~mm}$; $1 \phi 60 \mathrm{~mm} ; 2 \phi 50 \mathrm{~mm}$ ). In addition to these 32 (indicated in Figure 7 by the larger and solid points), 155 reservoirs (indicated in Figure 7 by the smaller and hollow points) were simulated and designed only to compose the behavior pattern of the efficiency curves $\mathrm{x}$ base area, with adoption of the discharge coefficient value referring to the hydraulic load of 2 meters. However, only the 32 reservoirs that meet the established criteria were analyzed for cost-efficiency.

The efficiency of the system was not so sensitive to the gradual reduction in the base area of the reservoir with the $50 \mathrm{~mm}$ outlet tube, while the reservoir cost was highly sensitive to this same variation (Figure 8). The initial reservoir design, with efficiency $=100 \%$, had an estimated cost of $\mathrm{R} \$ 137,365.44$, while the last reservoir of the series with a bottom discharge outlet made of a $50 \mathrm{~mm}$ diameter pipe had a cost of $\mathrm{R} \$ 87,340.79$. Among these reservoir alternatives, there was a decrease in efficiency of $3.2 \%$, while cost decreased $36.4 \%$ (reduction of $\mathrm{R} \$ 50,024.65$ ). However, continuing with the sequence of alternative reservoirs, the subsequent reduction of $15.1 \%$ in reservoir efficiency, going through the configurations with other outlet diameters, only reduced the total cost by approximately $16.8 \%$.

The reduction of the first $3.2 \%$ in efficiency contributed to the significant decrease in the base area and overall cost of the structure. However, there was no further significant reduction in efficiency, given that in financial terms the impact was not as significant as for the first $3.2 \%$ reduction. In fact, the last analyzed reservoir configuration, with two bottom discharge tubes of $50 \mathrm{~mm}$ in diameter, resulted in the lowest cost $(\mathrm{R} \$ 72,642.05)$ among all alternatives, with an efficiency of $82 \%$.

When analyzing the cost per unit of dampened outflow rate, there is a reduction of $\mathrm{R} \$ 2,779.48 \mathrm{per} \mathrm{L} / \mathrm{s}$ in the initial design 


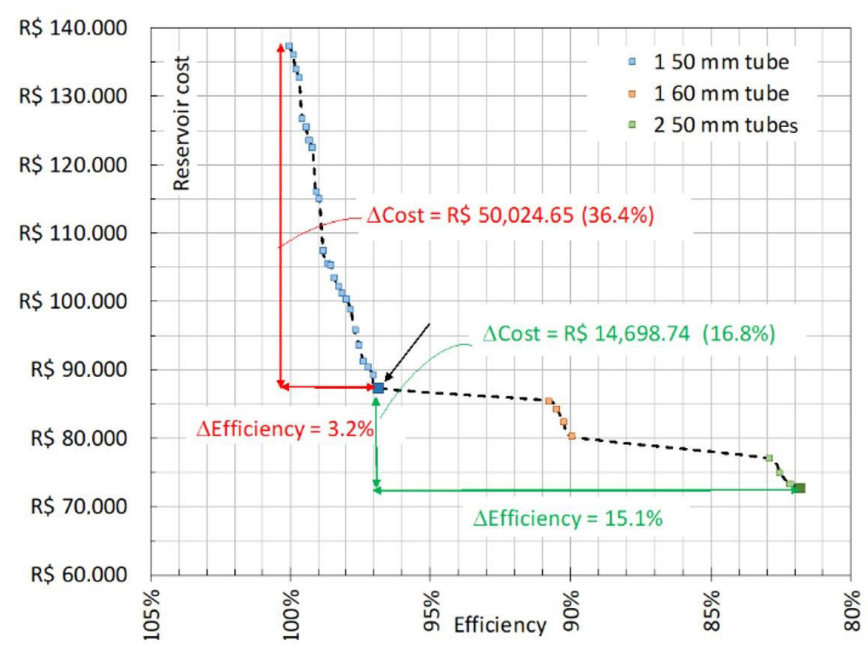

Figure 8. Total cost of reservoirs as a function of efficiency.

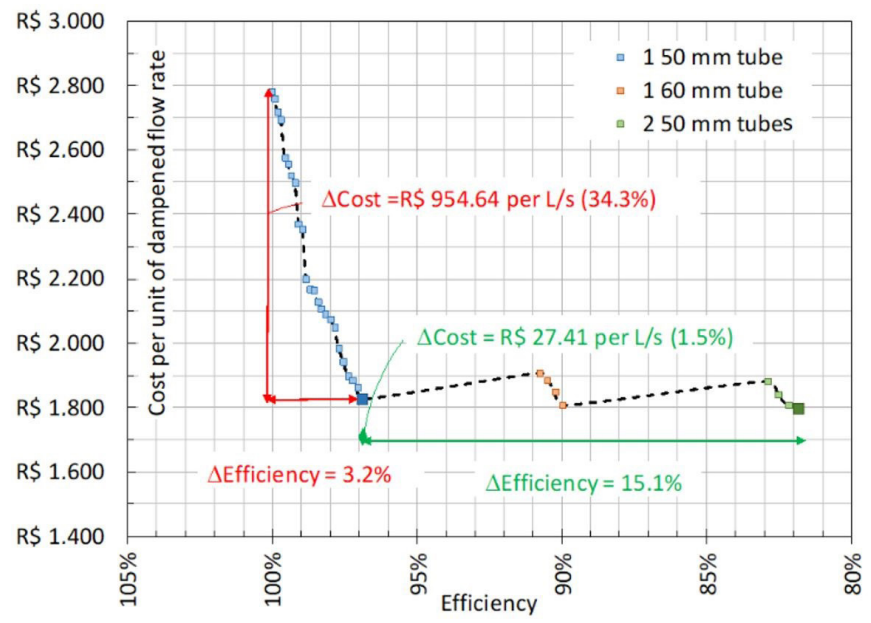

Figure 9. Costs of reservoirs per unit of dampened flow rate $(\mathrm{R} \$$ per $\mathrm{L} / \mathrm{s})$ as a function of efficiency. (1st reservoir) to $\mathrm{R} \$ 1,824.84$ per $\mathrm{L} / \mathrm{s}$ in the 24 th reservoir (the last of the set with $1 \phi 50 \mathrm{~mm}$ ), that is, a $34.3 \%$ decrease. From the 24th reservoir to the $32 \mathrm{nd}$ (last of the set with $2 \phi 50 \mathrm{~mm}$ ), the variation in cost per unit of dampened flow rate was only $1.5 \%$, with values close to $\mathrm{R} \$ 1,800.00$ per L/s (Figure 9).

Thus, over the set of 32 alternative reservoirs, the efficiency was reduced (from $100 \%$ to close to the established minimum efficiency value), and the cost was reduced, with the last reservoir having the lowest cost. However, the reservoir that showed the best cost-benefit ratio, combining the hydraulic, structural and economic views, was the reservoir in the 24th simulation. This is the reservoir sized just after drastically reducing the cost of the structure (indicated by the black arrow in Figure 8). The results of the hydraulic simulation of this reservoir are shown in Figure 6b, and its dimensions were $7.40 \times 7.40 \times 1.81 \mathrm{~m}$ with a $50 \mathrm{~mm}$ diameter discharge outlet. This reservoir configuration resulted in the storage and emptying of $88.2 \mathrm{~m}^{3}$ over 9 hours, with a reduction in the peak flow rate of $86.9 \%$. The efficiency of this reservoir, which is considered to be excellent, was $96.9 \%$ (19.7\% higher than the minimum efficiency, $77.1 \%$ ), which corresponded to the simulated maximum outflow at approximately 1.3 times the maximum pre-development flow rate.

The adoption of large reservoir base areas is not advantageous from the structural point of view since a nearly linear relationship $\left(\mathrm{R}^{2}\right.$ of 0.99$)$ was observed between the amount of steel and the base area of the reservoirs. This is particularly explained in view of the fact that the greater the span of the slabs, the greater the magnitude of the internal stresses, especially those of the cover slab, in addition to causing a greater demand on the reservoir walls.

Services related to the manufacture of reinforced concrete products governed the overall cost of the simulated structures, varying near approximately $64 \%$ of the total cost. As the cost of steel is quite high compared to the other inputs, it was evident that the decrease in the plant area was the major item responsible for the sharp drop in the overall cost of the structures (comparison between Figures 7 and 8). During the iterative process, there was an increase in the participation of costs with formworks in the global cost, ranging from $12 \%$ to $25 \%$, compared to the first and last simulated reservoirs (Figure 10). This is explained by

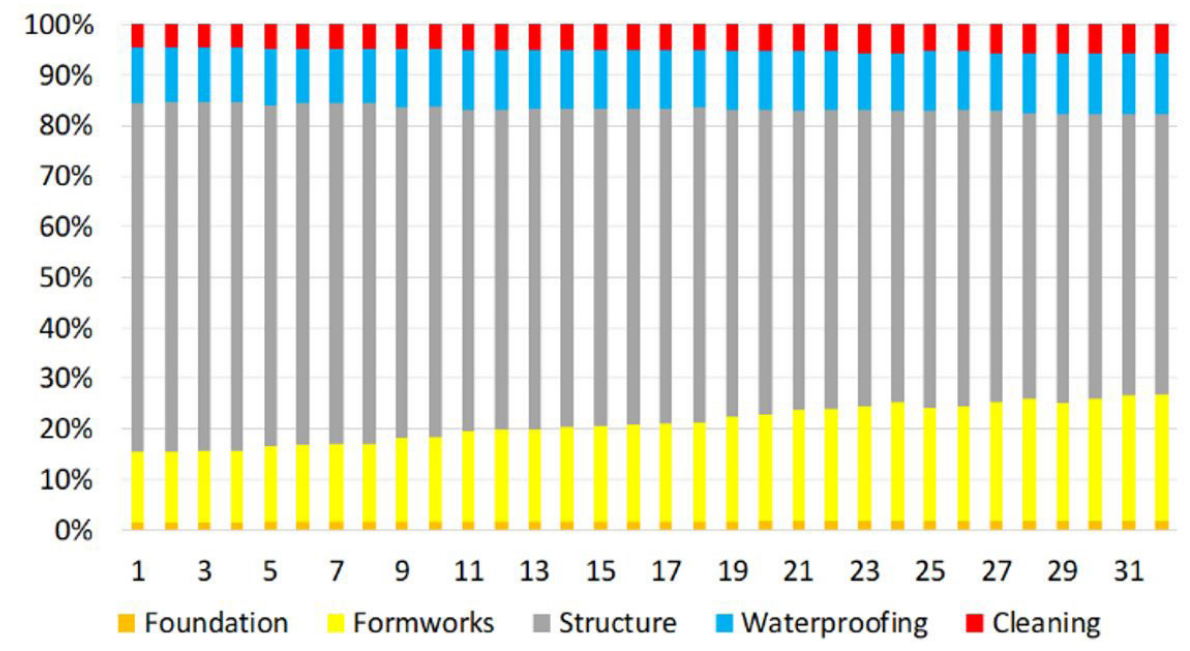

Figure 10. Percentages of cost types relative to total cost for each of the 32 reservoir configurations analyzed. 
the greater need for formwork area for the construction of the sidewalls as they become deeper. The foundation, waterproofing and cleaning costs varied near approximately $2 \%, 11 \%$ and $5 \%$ of the total cost, respectively, for all simulations.

The thicknesses of the bottom slab, cover, and walls of the 24th reservoir were 17, 21 and $25 \mathrm{~cm}$, respectively. The total cost of the device was $R \$ 87,340.79$, equivalent to $R \$ 18.75 / \mathrm{m}^{2}$ of land area under runoff control (rooftop area) and $\mathrm{R} \$ 881.43 / \mathrm{m}^{3}$ of internal reservoir volume. This amount was distributed as follows: structure (58\% of total cost); formworks (23\%); waterproofing $(11 \%)$; excavation $(2 \%)$ and cleaning $(6 \%)$. The cost per unit volume of the reservoir obtained was very close to that of Lengler et al. (2014) in the cost composition of a closed concrete macro-reservoir $\left(\mathrm{R} \$ 743.88 / \mathrm{m}^{3}\right)$.

\section{FINAL CONSIDERATIONS}

Traditional urban drainage mitigation measures have future consequences associated with high socioeconomic and environmental costs to society. In this sense, reservoirs for on-site control are a sustainable drainage solution that allows controlling the runoff source. This measure also contributes to greater equity among those involved because it holds the landowner responsible for the impact associated with modifying the natural runoff conditions of land, instead of punishing those around the land for negligent stormwater management.

Stormwater control with an on-site reservoir ideally aims at the return to the condition prior to land occupation. However, this study shows that stormwater control at this efficiency level can result in an oversized design and high costs. This may make it unfeasible to adopt the measure and discourage striving for sustainable control, even if the area of the selected reservoir is equivalent to only $1.18 \%$ of the coverage area and represents less than $1.92 \%$ of the construction cost of the building $(\mathrm{R} \$ 4,540,621.57$, calculated based on the CUB $/ \mathrm{m}^{2}$ of $\mathrm{R} \$ 975.01$, February 2017, for the standard project classification type CSL- 8 and normal finishing standard) (CBIC, 2018; ABNT, 2006). The relative share of the cost of the reservoir in the total building cost is small but represents a considerable monetary value. However, by systematically analyzing different reservoir configurations and allowing for control efficiencies slightly below $100 \%$, considerable reductions in structure dimensions and costs are achieved.

For the catchment area of $4,657 \mathrm{~m}^{2}$ studied, it was observed that a decrease of approximately $3 \%$ in efficiency provided a reduction of approximately $36 \%$ in the cost and of approximately $58 \%$ in the area occupied by the reservoir. Such an intervention is more likely to become attractive and economically viable, while the benefit to the downstream stormwater drainage system is essentially the same compared to the initial configuration with $100 \%$ efficiency. On the other hand, considering the possibility of increasing the post-development flow rate by up to three times, the cheapest reservoir solution is precisely the one with the closest efficiency to this configuration. However, it should be borne in mind that from a global perspective, looking solely from this point of view wastes the opportunity to adopt a measure with greater control of outflows, with higher cost-benefit.
The results obtained in the case study exemplify how the analysis of different alternatives can induce a decision between the reservoir outflow control level and cost that emphasizes different aspects than solely the minimization of costs or arbitrarily imposing a pre-defined control level (such as 100\%). In addition, this study showed the importance of structural dimensioning and considering construction processes in detail to calculate cost composition in order to analyze and select in a more realistic way the different alternative solutions.

\section{ACKNOWLEDGEMENTS}

National Council for Scientific and Technological Development $(\mathrm{CNPq})$ of Brazil for funding the research project to which this study is linked.

\section{REFERENCES}

ABNT - ASSOCIAÇÃO BRASILEIRA DE NORMAS TÉCNICAS. NBR 12721: avaliação de custos unitários de construção para incorporação imobiliária e outras disposições para condominios de edificios — procedimento. Rio de Janeiro: ABNT, 2006.

ABNT - ASSOCIAÇÃO BRASILEIRA DE NORMAS TÉCNICAS. NBR 6118: projeto de estruturas de concreto - procedimento. Rio de Janeiro: ABNT, 2014

ABNT - ASSOCIAÇÃO BRASILEIRA DE NORMAS TÉCNICAS. NBR 6120: cargas para o cálculo de estruturas de edificacõoes. Rio de Janeiro: ABNT, 1980.

AGRA, S. G. Estudo experimental de microrreservatórios para controle do escoamento superficial. 2001. 122 p. Dissertação (Mestrado em Recursos Hídricos e Saneamento Ambiental) - Instituto de Pesquisas Hidráulicas da Universidade Federal do Rio Grande do Sul, Porto Alegre, 2001.

ARAÚJO, J. M. Curso de concreto armado. v. 1-4. 3. ed. Rio Grande: Editora Dunas, 2010.

BAPTISTA, M.; NASCIMENTO, N.; BARRAUD, S. Técnicas compensatórias em drenagem urbana. 2. ed. Porto Alegre: ABRH, 2011. $318 \mathrm{p}$.

BRASIL. Instituto Brasileiro de Geografia e Estatística. Censo Brasil 2010. Brasília: IBGE, 2010. Available from: <http://censo2010. ibge.gov.br/>. Accessed on: 29 nov. 2016.

BRASIL. Ministério das Cidades. Programa drenagem urbana sustentável: manual para apresentação de propostas. Brasília: Secretaria Nacional de Saneamento Ambiental, 2006. 23 p.

BRENT, D. A.; GANGADHARAN, L.; LASSITER, A.; LEROUX, A.; RASCHKY, P. A. Valuing environmental services provided by local stormwater management. Water Resources Research, v. 53, n. 6, p. 4907-4921, 2017. http://dx.doi.org/10.1002/2016WR019776.

BRUNO, L. O.; AMORIM, R. S. S.; SILVEIRA, A. Estudo da redução do escoamento superficial direto em superfícies permeáveis. Revista Brasileira de Recursos Hídricos, v. 18, n. 2, p. 237-247, 2013. http:// dx.doi.org/10.21168/rbrh.v18n2.p237-247. 
BUTLER, D.; DAVIES, J. W. Urban drainage. 3rd ed. Oxon: Spon Press, 2010.632 p.

CAHILL, T. H. Low impact development and sustainable stormwater management. 1st ed. Hoboken, Nova Jersey: Wiley, 2012. 293 p. http://dx.doi.org/10.1002/9781118202456.

CAIXA ECONÔMICA FEDERAL. Sistema nacional de pesquisa de custos e indices da construção civil - relatórios de insumo e composição. Brasília: Caixa, 2017. Available from: <http://www.caixa.gov.br/ poder-publico/apoio-poder-publico/sinapi/relatorios/Paginas/ default.aspx>. Accessed on: 22 June 2017.

CANÇADO, V. L.; NASCIMENTO, N. O.; CABRAL, J. R. Cobrança pela drenagem urbana de águas pluviais: bases conceituais. Revista de Gestão de Águas da América Latina, v. 2, n. 1, p. 5-21, 2005.

CANHOLI, A. P. Drenagem urbana e controle de enchentes. 2. ed. São Paulo: Oficina de Textos, 2014. 302 p.

CARMEN, N. B.; HUNT, W. F.; ANDERSON, P. E. Volume reduction provided by eight residential disconnected downspouts in Durham, North Carolina. Journal of Environmental Engineering, v. 142, n. 10, p. 05016002, 2016. http://dx.doi.org/10.1061/(ASCE) EE.1943-7870.0001107.

CASTRO, A. S.; GOLDENFUM, J. A.; SILVEIRA, A. L.; MARQUES, D. M. Avaliação da evolução do comportamento quantitativo de pavimentos permeáveis no controle do escoamento superficial. Revista Brasileira de Recursos Hídricos, v. 18, n. 1, p. 263-273, 2013. http://dx.doi.org/10.21168/rbrh.v18n1.p263-273.

CBIC - CÂMARA BRASILEIRA DA INDÚSTRIA DA CONSTRUÇÃO. Custos unitários básicos de construção. Brasília: CBIC, 2018. Available from: <http://www.cub.org.br/cub-m2-estadual/ $\mathrm{PB} />$. Accessed on: 21 March 2018.

CEARÁ. Secretaria da Infraestrutura. Tabela de custos. Fortaleza: Seinfra, 2017. Available from: < http://www.seinfra.ce.gov.br/index. php/tabela-de-custos $>$. Accessed on: 22 June 2017.

COLLISCHONN, W.; DORNELLES, F. Hidrologia para engenharia e ciências ambientais. Porto Alegre: CD.G Casa de Soluções e Editora, 2013.

COSTA JÚNIOR, L. L.; BARBASSA, A. P. Parâmetros de projeto de micorreservatório, de pavimentos permeáveis e de previsão de enchentes urbanas. Engenharia Sanitaria e Ambiental, v. 11, n. 1, p. 4654, 2006. http://dx.doi.org/10.1590/S1413-41522006000100007.

DUAN, H.-F.; LI, F; YAN, H. Multi-objective optimal design of detention tanks in the urban stormwater drainage system: lid implementation and analysis. Water Resources Management, v. 30, n. 13, p. 4635-4648, 2016. http://dx.doi.org/10.1007/s11269-016-1444-1.

GENOVEZ, A.; LOMBARDI NETO, F.; SARTORI, A. Classificação Hidrológica de Solos Brasileiros para a estimativa da chuva excedente com o método do Serviço de Conservação do Solo dos Estados Unidos. Parte 1: Classificação. Revista Brasileira de Recursos Hídricos, v. 10, n. 4, p. 5-18, 2005. http://dx.doi.org/10.21168/rbrh.v10n4.p5-18.
GENZ, F. Parâmetros para previsão e controle de cheias urbanas. 1994. 184 p. Dissertação (Mestrado em Recursos Hídricos e Saneamento Ambiental) - Instituto de Pesquisas Hidráulicas da Universidade Federal do Rio Grande do Sul, Porto Alegre, 1994.

GURGEL, G. M.; RIGHETTTO, A. M. Crescimento urbano e seus impactos no sistema de drenagem de uma bacia em Natal, RN. Revista de Gestão de Aguas da América Latina, v. 13, n. 1, p. 54-68, 2016.

HAMEL, P.; DALY, E.; FLETCHER, T. D. Source-control stormwater management for mitigating the impacts of urbanisation on baseflow: a review. Journal of Hydrology, v. 485, p. 201-211, 2013. http://dx.doi.org/10.1016/j.jhydrol.2013.01.001.

HIXON, L. F.; DYMOND, R. L. Comparison of stormwater management strategies with an urban watershed model. Journal of Hydrologic Engineering, v. 20, n. 9, p. 04014091, 2014. http://dx.doi. org/10.1061/(ASCE)HE.1943-5584.0001099.

LAMERA, C.; BECCIU, G.; RULLI, M. C.; ROSSO, R. Green roofs effects on the urban water cycle component. Procedia Engineering, v. 70, p. 988-997, 2014. http://dx.doi.org/10.1016/j.proeng.2014.02.110.

LENGLER, C.; LEUCK, M. F.; MENDES, C. A. B. Modelo para criação de incentivo fiscal ao amortecimento de vazão em lote: simulação para o município de Porto Alegre (RS). Revista Brasileira de Recursos Hídricos, v. 19, n. 3, p. 295-307, 2014. http://dx.doi. org/10.21168/rbrh.v19n3.p295-307.

LI, C.; FLETCHER, T. D.; DUNCAN, H. P.; BURNS, M. J. Can stormwater control measures restore altered urban flow regimes at the catchment scale? Journal of Hydrology, v. 549, p. 631-653, 2017. http://dx.doi.org/10.1016/j.jhydrol.2017.03.037.

MENDIONDO, E.; MENDES, H. Histórico da expansão urbana e incidência de inundações: o caso da bacia do Gregório, São Carlos - SP. Revista Brasileira de Recursos Hídricos, v. 12, n. 1, p. 17-27, 2007. http://dx.doi.org/10.21168/rbrh.v12n1.p17-27.

PETRUCCI, G.; RIOUST, E.; DEROUBAIX, J.-F; TASSIN, B. Do stormwater source control policies deliver the right hydrologic outcomes? Journal of Hydrology, v. 485, p. 188-200, 2012. http:// dx.doi.org/10.1016/j.jhydrol.2012.06.018.

POMPEO, C. A. Drenagem urbana sustentável. Revista Brasileira de Recursos Hidricos, v. 5, n. 1, p. 15-23, 2000. http://dx.doi.org/10.21168/ rbrh.v5n1.p15-23.

PORTO ALEGRE. Departamento de Esgotos Pluviais. Manual de drenagem urbana. v. 4. Porto Alegre: Instituto de Pesquisas Hidráulicas, 2005. 159 p. (Plano diretor de drenagem urbana).

PORTO, R. M. Hidráulica básica. 4. ed. São Carlos: Escola de Engenharia de São Carlos, 2006. 540 p.

REZENDE, O. M.; MIGUEZ, M. G.; VERÓL, A. P. Manejo de águas urbanas e sua relação com o desenvolvimento urbano em bases sustentáveis integradas - estudo de caso dos rios Pilar-Calombé, em Duque de Caxias/RJ. Revista Brasileira de Recursos Hídricos, v. 18, n. 2, p. 149-163, 2013. http://dx.doi.org/10.21168/rbrh.v18n2.p149-163. 
SÃO PAULO. Manual de drenagem e manejo de águas pluviais - aspectos tecnológicos: fundamentos. v. 2. São Paulo: Secretaria Municipal de Desenvolvimento Urbano, 2012. 220 p.

SHUSTER, W. D.; BONTA, J.; THURSTON, H.; WARNEMUENDE, E.; SMITH, D. R. Impacts of impervious surface on watershed hydrology: a review. Urban Water Journal, v. 2, n. 4, p. 263-275, 2005. http://dx.doi.org/10.1080/15730620500386529.

SILVA JÚNIOR, M. A. B.; SILVA, S. R.; CABRAL, J. J. S. P. Compensatory alternatives for flooding control in urban areas with tidal influence in Recife - PE. Revista Brasileira de Recursos Hídricos., v. 22, p. e19, 2017. https://dx.doi.org/10.1590/2318-0331.011716040.

SILVA, K. L.; AZEVEDO, V. C. F.; LEITE, E. P. F. Mapeamento $e$ análise do uso e ocupação do solo da bacia do rio Cuiá a partir de imagem do satélite Quickbird. In: V CONNEPI - Congresso Norte Nordeste de Pesquisa e Inovação, 5., 2010, Maceió, AL. Anais... Maceió: IFAL, 2010.

SILVA, L. P.; SANTOS, C. A. G. Análise espacial dos riscos de erosão e inundação na bacia do rio Cuiá. Revista Brasileira de Recursos Hidricos, v. 15, n. 3, p. 21-32, 2010. http://dx.doi.org/10.21168/ rbrh.v15n3.p21-32.

SILVA, P. O.; CABRAL, J. J. S. P. Atenuação de picos de vazão em área problema: estudo comparativo de reservatórios de detenção em lote, em logradouros e em grande área da bacia. Revista Brasileira de Recursos Hidricos, v. 19, n. 2, p. 7-18, 2014. http://dx.doi.org/10.21168/ rbrh.v19n2.p7-18.

SILVEIRA, A. L. L.; GOLDENFUM, J. A. Metodologia generalizada para pré-dimensionamento de dispositivos de controle pluvial na fonte. Revista Brasileira de Recursos Hídricos, v. 12, n. 2, p. 157-168, 2007. http://dx.doi.org/10.21168/rbrh.v12n2.p157-168.

SILVEIRA, A.; BEMFICA, D.; GOLDENFUM, J. Análise da aplicabilidade de padrões de chuva de projeto a Porto Alegre. Revista Brasileira de Recursos Hídricos, v. 5, n. 4, p. 5-16, 2000. http://dx.doi. org/10.21168/rbrh.v5n4.p5-16.

SILVEIRA, A.; TUCCI, C.; CRUZ, M. Controle do Escoamento com Detenção em Lotes Urbanos. Revista Brasileira de Recursos Hidricos, v. 3, n. 4, p. 19-31, 1998. http://dx.doi.org/10.21168/ rbrh.v3n4.p19-31.

SOUZA, C. F.; CRUZ, M. A. S.; TUCCI, C. E. M. Desenvolvimento urbano de baixo impacto: planejamento e tecnologias verdes para a sustentabilidade das águas urbanas. Revista Brasileira de Recursos Hidricos, v. 17, n. 2, p. 9-18, 2012. http://dx.doi.org/10.21168/ rbrh.v17n2.p9-18.

SOUZA, V. C. B. Estudo experimental de trincheiras de infiltração no controle da geração do escoamento superficial. 2002. 151 p. Tese (Doutorado em em Recursos Hídricos e Saneamento Ambiental) - Instituto de Pesquisas Hidráulicas da Universidade Federal do Rio Grande do Sul, Porto Alegre, 2002.
SUDENE - Superintendência do Desenvolvimento do Nordeste. Mapa exploratório - reconhecimento de solos do município de João Pessoa. Recife: SUDENE, 1972. (Levantamento exploratório - reconhecimento de solos do Estado da Paraíba).

TASSI, R.; TASSINARI, L. C. S.; PICCILLI, D. G. A.; PERSCH, C. G. Telhado verde: uma alternativa sustentável para a gestão das águas pluviais. Ambiente Construído, v. 14, n. 1, p. 139-154, 2014. http://dx.doi.org/10.1590/S1678-86212014000100012.

TAVANTI, D. R.; BARBASSA, A. P. Análise dos desenvolvimentos urbanos de baixo impacto e convencional. Revista Brasileira de Recursos Hídricos, v. 17, n. 4, p. 17-28, 2012. http://dx.doi.org/10.21168/ rbrh.v17n4.p17-28.

TCPO. Tabela de composições de preços para orçamentos. 13. ed. São Paulo: Editora Pini, 2010. 640 p.

TUCCI, C. E. M. Gestão de águas pluviais urbanas. Brasília: Ministério das Cidades, 2005. 194 p.

TUCCI, C. E. M. Regulamentação da drenagem urbana no Brasil. Revista de Gestão de Água da América Latina, v. 13, n. 1, p. 29-42, 2016.

TUCCI, C. E. M.; MELLER, A. Regulação das águas pluviais urbanas. Revista de Gestão de Água da América Latina, v. 4, n. 1, p. 75-89, 2007.

TUCCI, C. E. M.; PORTO, R. L. L.; BARROS, M. T. Drenagem urbana. Associação Brasileira de Recursos Hídricos: Porto Alegre, 1995. $428 \mathrm{p}$.

TUCCI, C.; GOLDENFUM, J.; ARAUJO, P. Avaliação da eficiência dos pavimentos permeáveis na redução de escoamento superficial. Revista Brasileira de Recursos Hídricos, v. 5, n. 3, p. 21-29, 2000. http:/ / dx.doi.org/10.21168/rbrh.v5n3.p21-29.

TUNG, Y.-K. Uncertainty analysis and risk-based design of detention basin without damage function. Water Resources Research, v. 53, n. 5, p. 1-23, 2017. http://dx.doi.org/10.1002/2016WR020079.

VILLANUEVA, A.; TASSI, R. Análise do impacto dos microrreservatórios de lote nos custos de uma rede de drenagem urbana. Revista Brasileira de Recursos Hídricos, v. 9, n. 3, p. 89-98, 2004. http://dx.doi.org/10.21168/rbrh.v9n3.p89-98.

\section{Authors contributions}

Victor Santos Galvão Baptista: Contributed to literature review, study design, methodology development and application, results discussion and paper writing.

Adriano Rolim da Paz: Contributed to study design, results discussion and paper writing. 